\title{
"MAKAN YANG BENAR SEHATKAN BADAN": PROGRAM PENDIDIKAN GIZI SEIMBANG UNTUK ANAK USIA SEKOLAH DENGAN PENDEKATAN REGULASI DIRI
}

\author{
Risatianti Kolopaking'; Agus Firmansyah²; Jahja Umar ${ }^{3}$ dan Umi Fahmida ${ }^{1}$ \\ ${ }^{1}$ Gizi Masyarakat, SEAMEO TROPMED Universitas Indonesia, Jakarta \\ 2Kesehatan Anak, Fakultas Kedokteran Universitas Indonesia, Jakarta \\ ${ }^{3}$ Fakultas Psikologi, Universitas Islam Negeri Syarif Hidayatullah, Jakarta
}

\begin{abstract}
The school-aged years are a critical time for delivering nutrition education to children because that is the time that cognitive-motivational processes emerge as an important influence on food choices. Conventional methods of delivering nutritional message emphasize on knowledge acquisition; however, experiential knowledge is more effective to promote healthy eating behavior among children. The current study used self-regulatory approach and social cognitive learning technique to develop nutrition education program for 3rd and 4th grades mid-low income children. Until now, there has not been any study on nutrition education in Indonesia that focuses on developing skills and behaviors related to areas of food and eating habits. The general objective of the study is to identify the effectiveness of the program by assessing dietary intake as a combined measure of children's self-regulation of food choice, children's selfmotivation, and maternal self-efficacy on the home food environment. Based on formative study, culturally tailored and age-appropriate in-class lessons adapted from Indonesian food dietary guidelines were designed for mid- to low-income children in an urban area of Jakarta. Students received 24 in-class sessions, 45 minutes each session twice a week, for a 12-week intervention taught by nutrition professionals. Both school teachers and parents were involved in the program. Outcome evaluations were studied using a quasi-experimental design with the intervention $(n=137)$ and comparison $(n=120)$ groups combined for three assessment periods: pre-intervention, post-intervention and follow-up (12 weeks after post-intervention). Participants were pair of children and their mothers. To answer the research questions, a multiple group structural equation model (SEM) with a structured mean analysis was used. The results suggest that nutrition education program with a self-regulatory approach had a significant effect in improving children's self-regulatory behaviors in terms of food choice and maternal self-efficacy on home food environment. The results also showed that the program had a significant sustainable effect in terms of improving children's dietary intakes. Using self-regulatory model, the results suggest that there are two approaches to implement the program. One approach is to modify maternal self-efficacy on the home food environment to improve children's self-motivation and their dietary intake; another is to directly modify children's self-regulation of food choice to improve their dietary intake.
\end{abstract}

Keywords: school-aged children; nutrition education; maternal self-efficacy; self-motivation; self-regulation

\section{PENDAHULUAN}

$\mathrm{M}$ asa di sekolah dasar adalah masa yang kritis untuk memberikan pendidikan gizi, karena proses berfikir dan proses berkehendak mulai berperan dalam perilaku makan seorang anak'. Dengan semakin berkembangnya teknologi dan jaringan sistem makanan, anak-anak, khususnya mereka yang tinggal di daerah perkotaan menghadapi tantangan tersendiri dalam memilih makanan². Anak-anak terpapar pada beragam pilihan makanan, terutama paparan terhadap jenis makanan olahan yang disukai anak tetapi kurang memiliki nilai gizi yang optimal.

Hasil penelitian awal dari studi Kolopaking ${ }^{3}$ yang dilakukan pada keluarga berpenghasilan menengah ke bawah di Jakarta Timur menunjukkan bahwa para ibu cenderung memilih makanan yang cepat dan mudah disajikan tetapi kurang peduli terhadap kandungan gizinya. Anak-anak merekapun cenderung memilih jajanan daripada makan makanan utama, sehingga asupan gizi mereka kurang optimal. Sebagai akibat kurang seimbangnya asupan gizi, anak-anak di daerah ini menghadapi resiko beban ganda masalah giziं,4. Mereka bukan saja berisiko menghadapi masalah kekurangan gizi seperti kependekan atau kekurusan, yang berakibat pada kurang optimalnya pertumbuhan fisik dan kecerdasannya. Di lain sisi, mereka juga berisiko menghadapi masalah kelebihan gizi seperti kegemukan, yang dapat meningkatkan 
risiko beberapa penyakit degeneratif seperti hipertensi, diabetes, penyakit jantung pada masa dewasanya kelak.

Dari hasil riset kesehatan dasar tahun $2007^{5}$, tercatat bahwa masalah kekurangan gizi yang umum ditemui pada anak usia sekolah adalah pendek dengan prevalensi 32 persen. $\mathrm{Di}$ lain sisi prevalensi kegemukan, 17 persen terjadi di perkotaan dan 14 persen di perdesaan. Beban ganda masalah gizi memang merupakan tantangan bagi negara berkembang seperti Indonesia. Pendidikan gizi merupakan salah satu upaya preventif menghadapi masalah ini.

Pada keluarga berpenghasilan menengah ke bawah, pemilihan makanan memang dipengaruhi oleh ketidakstabilan pendapatan keluarga, selain itu kurangnya pengetahuan gizi juga mempengaruhi bagaimana mereka menentukan pilihan makanan yang tepat untuk disajikan bagi anggota keluarganya $a^{6,7,8,9,10}$. Untuk itu penelitian ini bertujuan membuat program pendidikan gizi di sekolah bagi anak usia sekolah dasar yang melibatkan guru dan orang tua. Pendidikan gizi seimbang diperlukan bagi para anak dan ibu11,12, pada keluarga berpenghasilan menengah ke bawah agar pendidikan gizi dapat membantu mereka mengembangkan kecakapan dalam memilih dan menyediakan makanan bergizi dengan biaya terjangkau yang bersumber dari lingkungan mereka sendiri.

Berbagai penelitian menunjukkan bahwa pendidikan gizi seimbang lebih efektif apabila difokuskan pada aspek perilaku13,14. Pendekatan yang terfokus pada perilaku menunjukkan bahwa program pendidikan gizi terpusat pada perubahan perilaku individu dalam pemilihan makanan, dan bukan hanya pada penyebarluasan informasi tentang makanan atau gizi secara umum saja. Sehingga, ada perubahan paradigma untuk mengubah target pendidikan gizi seimbang, yaitu dari bertujuan meningkatkan pengetahuan, ke perubahan faktor psikologis sebagai variabel perantara yang memengaruhi perubahan perilaku dalam pemilihan makanan.

Pada penelitian ini, pendekatan regulasi diri dalam pemilihan makanan digunakan sebagai kerangka pikir untuk mengembangkan program pendidikan gizi seimbang dan digunakan sebagai model evaluasi untuk mengukur efektivitas program ${ }^{15,16,17,18}$. Konsep regulasi diri banyak berhasil diterapkan dalam penelitian dan penerapannya pada bidang psikologi pendidikan ${ }^{16,19}$. Proses pendidikan dengan pendekatan regulasi pada pemilihan makanan mengarahkan anak untuk mampu mengelola pikiran, perasaan dan tindakannya dalam memilih beragam makanan menyehatkan yang tersedia di lingkungannya. Dalam penelitian ini, pendekatan regulasi diri dalam pemilihan makanan berlandaskan pada teori sosial kognitif yang berdasarkan penelitian-penelitian terbukti efektif dalam penerapan pendidikan gizi $20,16,21,22,23$. Berdasarkan teori sosial kognitif, faktor yang memengaruhi perubahan perilaku makan diidentifikasi dalam tiga kategori: faktor lingkungan, faktor personal, dan faktor perilaku. Dalam penelitian ini, self-efficacy ibu adalah faktor pengaruh yang diukur sebagai aspek lingkungan ${ }^{24,25}$. Motivasi diri dan regulasi diri anak adalah dua faktor pengaruh yang diukur sebagai aspek personal dari dalam diri seseorang ${ }^{16,18}$. Asupan gizi dalam memilih kelompok makanan adalah sebuah faktor pengaruh yang diukur sebagai aspek perilaku26,27.

Sampai saat ini, belum ada penelitian tentang pendidikan gizi seimbang dilakukan di Indonesia yang menilai indikator terpadu meliputi pengetahuan dan aspek sosial psikologi yang berkaitan dengan perilaku makan. Penelitian ini akan menguji bagaimana pendidikan gizi seimbang dapat memengaruhi asupan makanan anak dengan mengukur variable perantara dari perilaku makan yang menyangkut variabel psikologis dari regulasi diri anak dalam memilih makanan, motivasi diri anak, dan self-efficacy ibu dalam menyediakan makanan di rumah. Hal ini akan memberikan pemahaman yang lebih baik bagi para pendidik dalam ilmu gizi dan kesehatan untuk meningkatkan motivasi dan kemampuan individu dalam mempraktikkan perilaku makan yang sehat. Hasil penelitian ini diharapkan dapat memajukan temuan penelitian ilmiah yang terkait dengan pengembangan pedoman makan bagi masyarakat Indonesia.

\section{METODE PENELITIAN}

Untuk mengevaluasi dampak dari pendidikan gizi seimbang, digunakan rancangan evaluasi pra dan pascaintervensi ${ }^{28}$. Evaluasi dilakukan dalam tiga tahap. Pertama, pada tahap praintervensi yaitu sebelum program 
pendidikan dimulai (bulan Februari 2009). Evaluasi kedua dinilai pada akhir minggu kedua belas intervensi yaitu dalam kurun waktu antara bulan Mei 2009 sampai Juni 2009 (pascaintervensi). Kemudian, evaluasi lanjutan dilakukan pada minggu kedua belas dari pascaintervensi (Agustus 2009).

\section{Partisipan}

Murid kelas tiga dan empat serta para ibu mereka sejumlah 137 pasang berpartisipasi dalam penelitian ini. Mereka berasal dari sebuah sekolah dasar di kelurahan Kampung Melayu kecamatan Jatinegara. Daerah ini mewakili area perkotaan dengan penghasilan rendah sampai menengah di Jakarta Timur, Indonesia ${ }^{29}$. Kriteria partisipan penelitian adalah: (1) Pasangan ibu dan anaknya yang berumur $\geq 8$ tahun dan $\leq 10$ tahun; (2) Anak tampak sehat, tidak menderita penyakit menular kronis atau akut, bila demikian dia akan dikeluarkan dan dirujuk untuk perawatan; (3) Anak tidak memiliki masalah belajar dan psikologis, bila demikian dia akan dikeluarkan dan dirujuk untuk penanganan; (4) Anak tidak mengalami kurang berat badan yang parah (WHZ < -3 z score), bila demikian dia akan dikeluarkan dan dirujuk untuk perawatan; (5) Anak tidak menderita anemia parah $(\mathrm{Hb} \leq 70$ $\mathrm{g} / \mathrm{L})$, bila demikian dia akan dikeluarkan dan dirujuk untuk perawatan; (6) Latar belakang pendidikan ibu minimum sekolah dasar; (7) Skor pada Household Food Security Scale terklasifikasi dalam cukup makanan atau tidak cukup makanan tanpa kelaparan; (8) lbu bersedia bergabung dalam penelitian dengan menandatangani persetujuan dan dapat mengundurkan diri kapan saja dari penelitian ini tanpa ada sangsi. Penelitian ini mengikuti panduan etika dari The Council for International Organization of Medical Sciences ${ }^{30}$ dan mendapat persetujuan dari Komite Etika Penelitian Medis Fakultas Kedokteran, Universitas Indonesia, Jakarta, Indonesia.

\section{Alat ukur}

Ada dua macam alat ukur yang digunakan dalam penelitian ini. Pertama adalah untuk mengukur asupan makan. Asupan makan adalah perilaku makan yang diukur dengan menilai keragaman asupan kelompok makanan. Untuk validitas pengukuran asupan makanan, dilakukan dengan metode 24-hour recall yang mengikuti kaidah standardized four-stage protoco ${ }^{26}$. Anak diminta untuk membuat catatan makanan dalam dua hari sekolah dan satu hari akhir pekan sebelum para peneliti datang untuk melakukan 24-hour recall. Setiap makanan yang tercatat dari recall diberi kode ke dalam kelompok makanan menggunakan lembar skor keragaman makanan atau dietary diversity score $^{31,32,33}$.

Kedua adalah alat yang digunakan untuk mengukur variabel perantara dari asupan makanan. Variabel perantara adalah variabel psikologis yang digunakan untuk memprediksi perilaku makan. Alat yang digunakan untuk mengukur variabel perantara disebut alat ukur psikometrik. Ada tiga macam alat ukur psikometrik yang digunakan dalam penelitian ini: (1) regulasi diri anak, (2) motivasi diri anak, dan (3) self-efficacy ibu. Tiga alat ukur tersebut divalidasi dengan menggunakan tata cara penyusunan alat psikometrik ${ }^{34,35,36,37,38}$. Instrumen regulasi diri anak, motivasi diri anak, dan self-efficacy ibu dipraujikan. Validitas konstruk dari alat ukur tersebut dianalisis dengan menggunakan structural equation model (SEM) confirmatory factor analysis (CFA) $)^{39,34,35,40,41}$.

\section{Pendidikan gizi: "Makan yang Benar Sehatkan Badan"}

Program pendidikan gizi disusun berdasarkan tinjauan pustaka mengenai pendekatan regulasi diri dalam pendidikan gizi 16,42,14,43,44,45,46, pedoman umum gizi seimbang Indonesia ${ }^{47,48}$ dan hasil temuan penelitian formatif dengan pendekatan ekologi49, yang kemudian diintegrasikan bersama dengan sumber informasi lain dari para ahli gizi, psikolog pendidikan dan pekerja seni kreatif. Program pendidikan memiliki slogan "Makan yang Benar Sehatkan Badan".

Penyampaian materi pendidikan menggunakan pendekatan regulasi diri yang disesuaikan dengan tingkat pemahaman untuk murid kelas tiga dan empat sekolah dasar di area perkotaan yang berpenghasilan menengah ke bawah di Jakarta. Anak-anak ditingkatkan ketrampilannya agar mampu merencanakan, mengevaluasi, mengawasi diri dan mengendalikan apa yang sudah direncanakannya dalam proses memilih makan. Penggunaan pendekatan regulasi diri ini bertujuan untuk meningkatkan kesiapan berpikir 
yaitu mampu memotivasi diri sendiri, kesiapan bertindak yaitu mampu meregulasi diri dalam memilih makanan, dan keterampilan bertindak yaitu mampu mengkonsumsi makanan yang menyehatkan yang tersedia di lingkungan tempat tinggal mereka.

Program pendidikan gizi seimbang MBSB terdiri atas enam unit dan 24 sesi pelajaran. Seperti terlihat pada gambar 1 dan 2 , modul pendidikan terdiri atas: (1) Panduan pendidik untuk para guru yang menyediakan informasi lengkap bagi guru untuk menerapkan

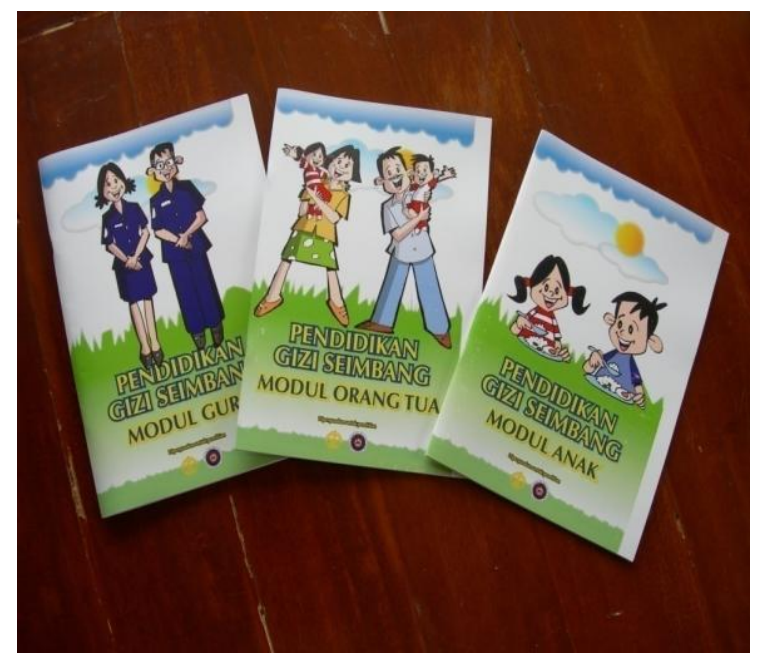

Gambar 1. Modul untuk Guru, Orang tua dan Anak

\section{Intervensi}

Pendidikan gizi diberikan dalam waktu 12 minggu. Ada tiga jenis kegiatan pendidikan: (1) Kegiatan dalam kelas untuk anak-anak, termasuk 24 sesi tatap muka selama 45 menit tiap sesi, dua kali seminggu, dan juga penulisan buku harian makanan setiap hari; (2) Kegiatan dalam kelas untuk para ibu yang terdiri atas enam sesi pertemuan, dua kali sebulan; (3) Kegiatan penguatan untuk anak-anak dan para ibu, seperti kegiatan-kegiatan untuk membuat perencanaan makan untuk anak dan keluarga, dan memperkuat kemampuan yang dibutuhkan untuk mencapai tujuan. Mereka yang terlibat dalam proses pendidikan adalah pendidik di bidang gizi, guru kelas dan kepala sekolah.

Analisis structural equation modeling (SEM) yang dilakukan untuk menjawab hipotesis pertanyaan penelitian. Tujuan dari penelitian adalah untuk menguji perbedaan nilai rerata dalam tiga periode pengukuran dan juga untuk meneliti model yang cocok untuk dapat kegiatan program para murid; (2) Buku kerja siswa yang berisi informasi tentang perilaku kunci mengenai kebersihan, kesehatan badan, dan makan yang sehat, dengan menyajikan cerita interaktif, dan permainan; (3) Buku pegangan untuk ibu yang digunakan untuk menginformasikan kepada para ibu tentang materi pendidikan dan untuk memonitor kebiasaan yang dilakukan anak-anak mereka; (4) Poster pedoman makan seimbang untuk anak ${ }^{50}$.

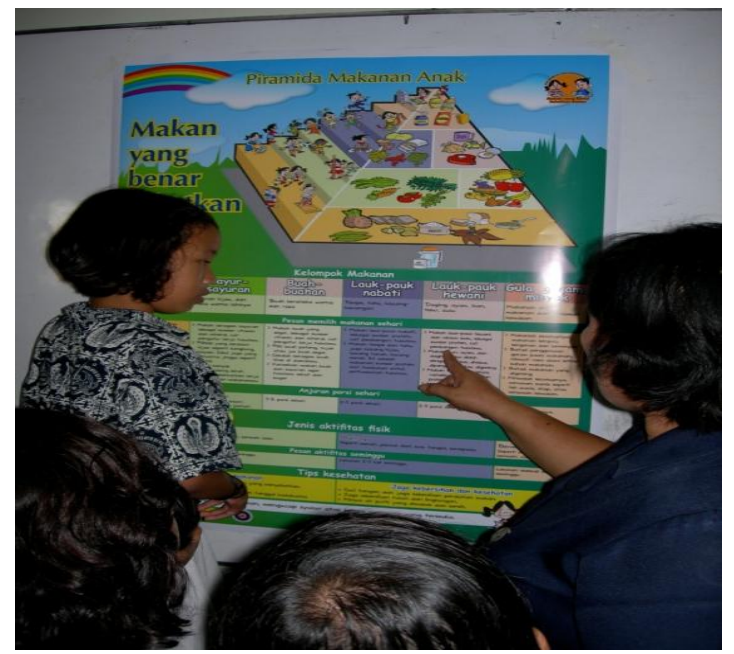

Gambar 2. Poster Piramida Makanan Anak

diaplikasikan dalam tiga periode pengukuran tersebut. Untuk tujuan ini penelitian ini menggunakan multigroup SEM structured mean analysis (Kaplan, 2000).

\section{HASIL DAN BAHASAN}

\section{Karakteristik Anak dan Keluarga}

Secara umum, karakteristik anak dan keluarga terlihat pada Tabel 1. Apabila dilihat dari nilai rerata $\mathrm{WHZ}$ anak terlihat condong ke kiri $(-0,2 \pm 1,5)$. Hal ini merefleksikan bahwa anak-anak pada populasi penelitian berisiko menghadapi kekurangan gizi tapi masih tetap dalam pertumbuhan normal9,26. Pendidikan ibu yang terlibat dalam penelitian ini sebayak $50,4 \%$ Iulusan Sekolah Dasar atau Sekolah Menengah Pertama. Sebanyak 59,9\% keluarga memilili penghasilan diatas Upah Minimum Regional (UMR) DKI Jakarta. 
Tabel 1

Karakteristik Anak dan Keluarga

(Berdasarkan pertanyaan terseleksi dari kuesioner)

\begin{tabular}{ll}
\hline Variabel & \multicolumn{1}{c}{$\begin{array}{c}\text { Participan } \\
(\mathrm{n}=137)\end{array}$} \\
\hline Usia Anak & $9,67 \pm 0,8$ \\
Perempuan & $71(51,8)$ \\
WHZ (weight per height z score) & $-0,2 \pm 1,5$ \\
Jumlah anggota keluarga & $5 \pm 2$ \\
Penghasilan keluarga (Rp)/bulan & $1.494 .343 \pm 704.365$ \\
$\geq$ UMR DKI Jakarta $(\mathrm{n}, \%)^{3}$ & $82(59,9)$ \\
Belanja makan (Rp)/hari & $39.416 \pm 15.380$ \\
Usia Ibu (tahun) & $37.0 \pm 5.7$ \\
Pendidikan Ibu $\leq 9$ tahun $4(\mathrm{n}, \%)$ & $69(50,4)$ \\
\hline
\end{tabular}

${ }^{1}$ Nilai ditulis sebagai: nilai rerata \pm SD; jumlah (\%); *signifikan pada $p<0.05 .{ }^{3}$ Berdasarkan upah minimum regional (UMR) DKI Jakarta 2009 Rp.1.069.865,00; ${ }^{4}$ Lama bersekolah: $\leq 9$ tahun(lulus SD atau SMPI)

\section{Efek pendidikan gizi seimbang}

Seperti terlihat pada Tabel 2, intervensi pendidikan gizi seimbang berdampak signifikan untuk meningkatkan regulasi diri anak dalam memilih makanan $(-1,57)$ dan juga meningkatkan self-efficacy ibu dalam menyediakan makanan di rumah $(-1,11)$. Pada gilirannya, pendidikan gizi seimbang dengan pendekatan regulasi diri memiliki dampak berkelanjutan dalam meningkatkan asupan makan anak-anak. Asupan makan anak dalam memilih makanan yang beragam dari pasca ke tindak lanjut meningkat secara signifikan $(0,26)$.
Namun, data tersebut tidak mendukung hipotesis bahwa pendidikan gizi seimbang memiliki dampak berkelanjutan untuk meningkatkan self-efficacy ibu. Self-efficacy ibu dari pasca intervensi ke tindak lanjut menurun secara signifikan $(-0,59)$. Hal tersebut mungkin disebabkan oleh proses pendidikan yang relatif singkat, sehingga tidak memberikan dampak berkelanjutan untuk para ibu. Pendidikan untuk para ibu dapat dilakukan untuk periode yang lebih lama atau diberikan secara berkala untuk memberikan dampak yang berkelanjutan.

Table 2. Efek Pendidikan Gizi

(Menggunakan analisa Structural Equation Modeling)

\begin{tabular}{|c|c|c|c|c|}
\hline Varibel & & alisa arah ${ }^{1,2}$ & $\mathrm{NP}^{3}$ & $t$-value ${ }^{4}$ \\
\hline \multirow[t]{2}{*}{ Asupan Makan } & Pra & $\rightarrow$ Pasca & 0.20 & TS \\
\hline & Pasca & $\rightarrow$ Tindak lanjut & 0.26 & 1.99 \\
\hline \multirow[t]{2}{*}{ Regulasi diri } & Pra & $\rightarrow$ Pasca & -1.57 & -10.53 \\
\hline & Pasca & $\rightarrow$ Tindak lanjut & -0.20 & TS \\
\hline \multirow[t]{2}{*}{ Motivasi Diri } & Pra & $\rightarrow$ Pasca & 0.07 & TS \\
\hline & Pasca & $\rightarrow$ Tindak lanjut & 0.01 & TS \\
\hline \multirow[t]{2}{*}{ Self-efficacy lbu } & Pra & $\rightarrow$ Pasca & -1.11 & -9.63 \\
\hline & Pasca & $\rightarrow$ Tindak lanjut & -0.59 & -5.38 \\
\hline
\end{tabular}


1 Untuk mengukur perbedaan rerata, digunakan SEM multiplegroup with structured mean in repeated measured ; kelompok pascaintervensi ditetapkan dengan nilai 0 dan dibuat sebagai kelompok acuan; ${ }^{2}$ Chi square $=69,29$; df=494; RMSEA=0,05; ${ }^{3}$ $\mathrm{NP}=$ nilai parameter pada pra ke pascaintervensi nilai parameter negatif menunjukkan bahwa nilai rerata pada pascaintervensi lebih besar dibandingkan dengan praintervensi; pada pascaintervensi ke tindak lanjut, nilai parameter positif menunjukkan bahwa nilai rerata pada tindak lanjut lebih besar daripada pascaintervensi.; ${ }^{4}$ signifikan pada $t$-value $\geq 1,96, \rho=0,05$; TS= tidak signifikan.

\section{Penggunaan model regulasi diri}

Gambar 3 menunjukkan hasil analisis arah yang signifikan dari model regulasi diri. Hasil penelitian ini memperlihatkan bahwa model hipotetis dari model regulasi diri didukung oleh data. Hasilnya menunjukkan bahwa regulasi diri anak dalam memilih makanan berdampak positif pada asupan makanannya $(0,17)$. Namun, motivasi diri anak dan self-efficacy ibu tidak berdampak yang signifikan pada regulasi diri anak. Di sisi lain, motivasi diri anak berdampak positif pada asupan makanan $(0,36)$. Sedangkan, self-efficacy ibu berdampak positif pada motivasi diri anak $(0,30)$.

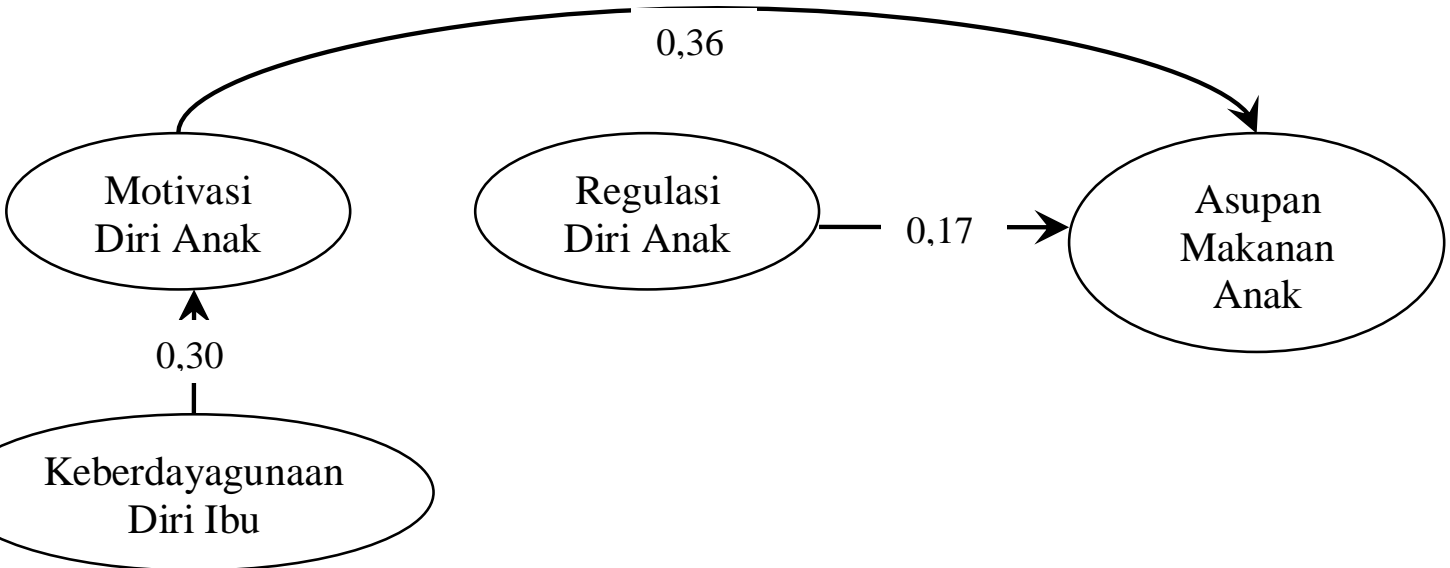

Gambar 3. Model regulasi diri menggunakan Structural Equation Modeling (hanya analisis arah yang signifikan yang disajikan) ${ }^{1,2,3,4}$

${ }^{1}$ Untuk menguji model digunakn SEM multiplegroup with structured mean in repeated measured; ${ }^{2}$ Chi square=691.29; $\mathrm{df}=494$; RMSEA $=0.05 ;{ }^{3}$ Nilai parameter positif menunjukkan ada efek positif dari variabel yang dihipotesakan; ${ }^{4}$ signifikan pada $t$-value $\geq 1.96, \rho=0.05$; TS= tidak signifikan.

\section{SIMPULAN DAN SARAN}

Hasil penelitian membuktikan bahwa program pendidikan gizi seimbang "Makan yang Benar Sehatkan Badan" berdampak signifikan untuk meningkatkan regulasi diri anak dalam memilih makanan dan juga meningkatkan selfefficacy ibu dalam menyediakan makanan di rumah. Penggunaan pendekatan regulasi diri dalam pendidikan gizi juga memiliki dampak berkelanjutan untuk meningkatkan perilaku makan anak dalam memilih beragam makanan yang menyehatkan. Dengan keterampilan ini, anak dari keluarga berpenghasilan menengah ke bawah lebih selektif untuk memilih makanan. $\mathrm{Di}$ lain sisi, untuk mendapatkan dampak berkelanjutan, intervensi pendidikan gizi seimbang bagi para ibu dapat diberikan secara berkala.
Hasil penelitian ini menemukan bahwa hipotetis dari model regulasi diri didukung oleh data. Hasil menunjukkan bahwa ada dua pendekatan yang dapat digunakan dalam menerapkan program pendidikan gizi seimbang "Makan yang Benar Sehatkan Badan" ini. Pertama, untuk meningkatkan asupan makanan anak, pendidikan gizi diberikan melalui ibu untuk meningkatkan self-efficacy ibu dalam menyediakan makanan di rumah, yang berdampak langsung pada peningkatan motivasi diri anak dan selanjutnya berdampak langsung pada asupan makanan anak. Kedua, pendidikan gizi diberikan langsung pada anak untuk meningkatkan regulasi diri anak dalam memilih makanan, yang kemudian terbukti secara signifikan berdampak langsung pada peningkatan asupan makanannya. 
Kelebihan dari penelitian ini adalah (1) Materi pendidikan gizi dirancang sesuai dengan umur dan proses penyampaian materi pendidikan dikembangkan berdasarkan teori perubahan perilaku yang berkaitan dengan regulasi diri dalam memilih makanan; (2) Penggunaan pendekatan dan model regulasi diri sebagai alat evaluasi terpadu adalah hal yang baru dalam penelitian intervensi pendidikan gizi. Dengan menggunakan pendekatan ini, perubahan perilaku makan dapat diprediksi dengan mengukur variabel perantaranya, terutama apabila intervensi dilakukan dalam waktu yang pendek. Sampai saat ini, di Indonesia, belum ada penelitian tentang pendidikan gizi seimbang berbasis sekolah dengan pendekatan teori perubahan perilaku yang menilai aspek sosial psikologis yang berkaitan dengan perilaku makan. Penelitian serupa ini, akan memberikan pemahaman yang lebih baik bagi para pendidik dalam ilmu gizi dan kesehatan untuk meningkatkan motivasi dan kemampuan individu dalam mempraktikkan perilaku makan yang menyehatkan.

Diperlukan lebih banyak lagi penelitian lanjutan tentang pendidikan gizi berbasis sekolah untuk menguji apakah pendidikan gizi seimbang bisa diajarkan: (1) sebagai topik yang tergabung dalam satu mata pelajaran tertentu misalnya pendidikan gizi masuk dalam pelajaran ilmu pengetahuan alam; (2) sebagai topik yang dipadukan ke dalam beberapa mata pelajaran misalnya terintegrasi dalam mata pelajaran matematika, ilmu pengetahuan sosial, ilmu pengetahuan alam dan olah-raga; (3) sebagai mata pelajaran khusus tentang pendidikan gizi seimbang.

Hasil-hasil penelitian berkaitan dengan pendidikan gizi ini, tentunya dapat menjadi data berbasis bukti dalam menyusun kebijakan dan program pendidikan gizi dan kesehatan di Indonesia, baik di Kementerian Kesehatan maupun Kementerian Pendidikan Nasional. Untuk menerapkan dan mengembangkan program pendidikan gizi seimbang berbasis sekolah perlu dipertimbangkan hal-hal berikut: (1) Adanya keterpaduan antara muatan pengetahuan gizi, sistem monitoring dan sistem evaluasi, serta adanya sumber daya manusia yang profesional untuk memastikan bahwa semua komponen program berlandaskan pada pengetahuan, teori dan hasil penelitian terkini;
(2) Melibatkan orang tua secara aktif dalam kegiatan berbasis sekolah untuk mendukung motivasi diri anak; (3) Untuk masyarakat dengan latar belakang sosio-ekonomi menengah kebawah, pendekatan pendidikan gizi seimbang sebaiknya mempertimbangkan keterbatasan struktural, material, ekonomi dan kontekstual yang membentuk dan membatasi kehidupan mereka. Sehingga, program pendidikan melalui sekolah ini, dapat lebih difokuskan pada konteks di mana mereka hidup dan tinggal, dan bagaimana hal ini mempengaruhi berfungsinya aspek psikososial dan perilaku yang berkaitan dengan pemilihan makanan dan kesehatan.

Gerakan promosi kesehatan tentang gizi seimbang melalui sekolah dapat menjadi sarana tepat bagi anak. Dan seyogyanya, gerakan ini dapat menjadi gerakan nasional yang melembaga dan berkelanjutan, bukan hanya sekedar gerakan yang sporadis saja.

\section{RUJUKAN}

1. Birch, L., Jennifer S., Ventura, A.Influences on the development of children's eating behaviours: From infancy to adolescence. Canadian Journal of Dietetic Practice and Research 2006, 68(1), S1-5.

2. Popkin, B. The shift in stages of nutrition transition in the developing world differs from past experiences. Public Health Nutrition 2004, 5(1A), 205-214.

3. Kolopaking, R., Bardosono, S., Famida U. (in press). Maternal Self-efficacy on the home food environment: a qualitative study among low-income mothers of nutritionally at risk children in an urban area of Jakarta. Journal of Nutrition Education and Behavior, accepted 27 October 2009.

4. Kennedy, G., Nantel, G., Shetty, P. Assessment of the double burden of malnutrition in six case study countries. In FAO Food and Nutrition Paper No. 84. The double burden of malnutrition: case studies from six developing countries (pp.1-20). Rome: FAO, 2006.

5. Kementerian Kesehatan Republik Indonesia. Riset Kesehatan Dasar Indonesia: Laporan Nasional 2007. Jakarta: Kemkes RI, 2008. 
6. Kennedy L.N., Hunt C., Hodgson P. Nutrition Education Program Based on EFNEP for low-income Women in the United Kingdom: "Friend with Food". Journal Nutrition Education 1998, 30, 9-99.

7. Guldan, G.S., Fan, H., Xiao Ma, Zong-Zan $\mathrm{Ni}$, Xia Xiang, Ming-Zhen Tang. Culturally appropriate nutrition education improves infant feeding and growth on rural Sichuan, china. Journal Nutrition 2000, 13, 12041211

8. Ferguson, E., Darmon, N., Fahmida, U., Fitriyanti, S., Harper, T.M., Premachandra, I.M. Design of optimal food-based complimentary feeding recommendations and identification of key "problem nutrients" using goal programming. The Journal Nutrition 2006, 136, 2399-2404.

9. Levenson, F.J, Barney, J., Bassett, L., Schultink, W. Utilization of positive deviance analysis in evaluating communitybased nutrition programs: an application to the Dular program in Bihat, India. Food and nutrition Buletin 2007, 28(3), 259-265.

10. Scaglioni, S., Salvioni, M., Galimberti, C. Influence of parental attitude in the development of children eating behaviour. British Journal of Nutrition 2008, 99(1), S22-S25

11. Soekidjo, N. Pengaruh metoda permainan dan ceramah dalam pendidikan gizi masyarakat terhadap status gizi anak balita. Disertasi. Jakarta: Fakultas Kesehatan Masyarakat UI, 1988.

12. Madanijah, S. (2003). Education Model "GPI-PSI-SEHAT" (Nutrition-PsychosocialHealth) for Mother, the impact on mother behavior, caring environment, food consumption and nutritional status of children under two years. (Doctoral desertation). Bogor: Institut Pertanian Bogor, 2003.

13. Achterberg, A., \& Miller, C. Is one theory better than another in nutrition education? A viewpoint: More is better. Journal of Nutrition Education and Behavior 2004, 36, 40-42.

14. Contento, I.R. Nutrition education: linking research, theory, and practice. Sudbury, Massachussetts: Jones and Barlett Publishers, 2007.
15. Contento, I.R., Randell, J.S., Basch, C.E. Review and analysis of evaluation measures used in nutrition education intervention research. Journal of Nutrition Education and Behavior(2002, 34, 2-25.

16. Zimmerman, B.J. Attainning Self-regulation: a social cognitive perspective. In $M$. Boekaerts, P. R. Pintrich, M. Zeidner (Eds.), Handbook of self-regulation. USA: Elsevier Academic Press, 2005.

17. Maes, S., \& Gebhardt, W. Self-regulation and health behavior: the health behavior model. In M. Boekaerts, P. R. Pintrich, M. Zeidner (Eds.). Handbook of self-regulation USA: Elsevier Academic Press, 2005.

18. Contento, I.R. Nutrition education: linking research, theory, and practice. Sudbury, Massachussetts: Jones and Barlett Publishers, 2007.

19. Zimmerman, B.J., \& Schunk, D.H. Motivation: an essential dimension of selfregulated learning. In D.H. Schunk, B.J. Zimmerman (Eds.) Motivation and self regulated learning: Theory, research and applications . New York: Lawrence Erlbaum Associates, 2008.

20. Bandura, A. Self-efficacy in changing society. Cambridge UK: University Press, 1995.

21. Auld, G.W., Romaniello, C., Heimendenger, J., Hambidge, C., Hambidge, M. Outcome from a school-based nutrition education program using resource teachers and cross-disciplinary models. Journal of Nutrition Education 1998, 30(5), 268-280.

22. Dollahite, J., Hosig, K.W., White, K.A., Rodibaugh, R., Holmes, T.M. Impact of school-based community intervention program on nutrition knowledge and food choices in elementary school children in the rural Arkansas Delta. Journal of Nutrition Education 1998, 30(5), 289-301.

23. Matvienko, O. Impact of a Nutrition Education Curriculum on Snack Choices of Children Ages Six and Seven Years. Journal of Nutrition Education and Behavior 2007, 39(5), 281-285.

24. Coleman, P.K., \& Karraker, K.H. Selfefficacy and parenting quality: findings and future applications. Developmental Review1998, 18(1), 47-85. 
25. Coleman P.K., \& Karraker K.H. Maternal self-efficacy beliefs, competence in parenting, and toddler's behavior and developmental status. Infant Mental Health 2003., 24, 126-148.

26. Gibson, R. S. Principle of Nutritional Assessment (2 ${ }^{\text {nd }}$ ed.). New York: Oxford University, 2005.

27. Satter, E. Eating Competence: Definition and Evidence for the Satter Eating Competence Model. Journal of Nutrition Education and Behavior 2007, 39, S142S153.

28. Cottrel, R.R., \& McKenzie, J. F. Health promotion \& education research methodhs: Using the five-chapter thesis/dissertation model. Sudbury, Massachusetts: Jones and Bartlestt Publishers, 2005.

29. BPS-DKI Jakarta. Jakarta in figure 2007. Jakarta: Statistical Bureau of DKI Jakarta, 2007.

30. CIOMS-Council for International Organizations of Medical Sciences. International ethical guideline for epidemiological studies. World Health Organization: Geneva, 2002.

31. Daniels, M.C., Popkin B.M., Truong Y.K. Dietary diversity score can be improved thorugh the use of portion requirements: an analysis in young Filipino children. European Journal of Clinical Nutrition 2009, 63, 199-208.

32. Swindale, A., \& Bilinsky. Household Dietary Diversity Score (HDDS) for measurement of household food access: indicator guide. Washington DC: Food and Nutrition. Assistance Project to Educational Development, $2006 . \quad$ Website: www.fantaproject.org.

33. Steyn, N.P., Nel J.H, Nantel G., Kennedy G., Labadarios D. Food variety and dietary diversity scores in children: are they good indicators of dietary adequacy? Publich Health Nutrition 2005, 9(5), 644-650.

34. Byrne, B.M. (1998). Structural equation modeling with Lisrel, Prelis and Simplis: Basic concepts, applications and programming. New Jersey: Lawrence Erlbaum Associates, Inc.
35. Kaplan, D. Structural Equation Modelling: foundation and extensions. California: Sage Publication, 2000.

36. Cohen, R.J., \& Swerdlik, M.E. Psychological testing and assessment. New York: McGraw-Hill, 2005.

37. Thompson, V.J., Christin M.B., Tom Baranowski, Karen W.C. Self-efficacy and norm measures for lunch fruit and vegetable consumption are reliable and valid among fifth grade students. Journal Nutrition Education and Behavior 2007, 39, 2-7.

38. Penkilo, M., George, G.C., Holescher, D. Reproducibility of the school-based nutrition education monitoring questionnaire among fourth-grade students in Texas. Journal of Nutrition Education and Behavior 2008, 40, 20-27.

39. Jöreskog, K.G., \& Sörbom, D. Lisrel 8: User's Reference Guide. Chichago: Scientific Software International, 1996.

40. Du Toit, M and Du Toit. Interactive Lisrel: User Guide. Lincolnwood, IL: Scientific Software, 2001.

41. Umar, J. Introduction to Lisrel. Paper presented at structural equation model training, Indonesian Institute of Assessment, Jakarta, August 2008.

42. Briggs, M. Nutrition education: an integral component of child nutrition programs. In J. Martin \& C. Oakley (Ed). Managing child nutrition programs: leadership for excellence $\left(2^{\text {nd }}\right.$ ed.). Sudbury, Massachusetts: Jones and Bartlett Publishers, 2008.

43. Fogarty, R. (1994). Teach For Metacognitive Reflection. Victoria, Australia: Hawker Brownlow Education.

44. Maes, S., \& Gebhardt, W. Self-regulation and health behavior: the health behavior model. In M. Boekaerts, P. R. Pintrich, M. Zeidner (Eds.). Handbook of self-regulation. USA: Elsevier Academic Press, 2005.

45. Powell, R.G., \& Caseau. Classroom communication and diversity: ehnancing instructional practise. New Jersey USA: Lawrence Erlbaum Associates, Publishers, 2004. 
46. Rhee, C.R., \& Pintrich, P.R. (2004). Teaching to facilitate self-regulated learning. In J. Ee, A. Chan, O. Tan (Eds.), Thinking about thinking: what educator need to know. Singapore: McGraw Hill, 2004.

47. Kemenkes-Kementerian Kesehatan Republik Indonesia. Panduan 13 Pesan Dasar Gizi Seimbang. Jakarta Departemen Kesehatan RI, 1995.

48. Kemenkes-Kementerian Kesehatan Republik Indonesia. Pedoman Umum Gizi Seimbang (Panduan untuk petugas). Jakarta: Direktorat Jenderal Bina
Kesehatan Masyarakat: Direktorat Gizi Masyarakat, 2002

49. Bronfenbrenner, U. The Ecology of Human Development: Experiments by Nature and Design. Cambridges, Mass: Harvard University Press, 1979.

50. Kolopaking, R., Fahmida, U., Firmansyah, A., Minarto. A content analysis of dietary and physical activity guideline for elementary school children: Study in urban area of Jakarta, Indonesia. Dipresentasikan pada International Congress of Nutrition, 7 October 2009 in Bangkok Thailand. 